STATE OF FLORIDA

STATE BOARD OF CONSERVATION

DIVISION OF GEOLOGY

FLORIDA GEOLOGICAL SURVEY

Robert $O$. Vernon, Director

INFORMATION CIRCULAR NO. 51

\title{
GROUND WATER IN THE IMMOKALEE AREA, COLLIER COUNTY, FLORIDA
}

\author{
By \\ Henry J. McCoy \\ U. S. Geological Survey \\ Prepared by the \\ UNITED STATES GEOLOGICAL SURVEY \\ in cooperation with the \\ COLLIER COUNTY COMMISSION \\ and the \\ FLORIDA GEOLOGICAL SURVEY
}

TALLAHASSEE

1967 



\title{
STATE OF FLORIDA \\ STATE BOARD OF CONSERVATION \\ DIVISION OF GEOLOGY
}

FLORIDA GEOLOGICAL SURVEY

Robert O. Vernon, Director

INFORMATION CIRCULAR NO. 51

\section{GROUND WATER IN THE IMMOKALEE AREA, COLLIER COUNTY, FLORIDA}

\author{
By \\ Henry J. McCoy \\ U. S. Geological Survey \\ Prepared by the \\ UNITED STATES GEOLOGICAL SURVEY \\ in cooperation with the \\ COLLIER COUNTY COMMISSION \\ and the \\ FLORIDA GEOLOGICAL SURVEY
}

TALLAHASSEE

1967 
Completed manuscript received

December 1, 1966

Printed by the Florida Geological Survey (job no. 208)

Tallahassee 


\section{TABLE OF CONTENTS}

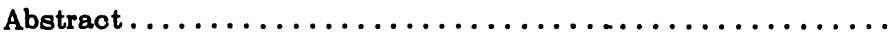

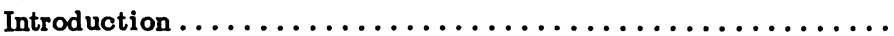

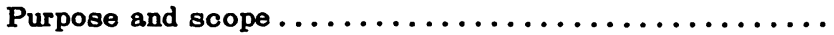

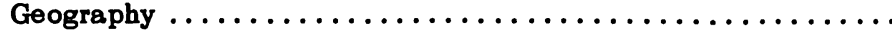

Location and general features $\ldots \ldots \ldots \ldots \ldots \ldots \ldots \ldots$

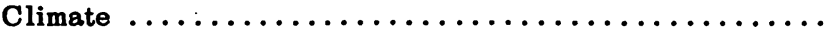

Topography and.drainage $\ldots \ldots \ldots \ldots \ldots \ldots \ldots \ldots \ldots$

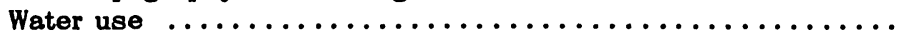

Test-well drilling $\ldots \ldots \ldots \ldots \ldots \ldots \ldots \ldots \ldots \ldots \ldots$

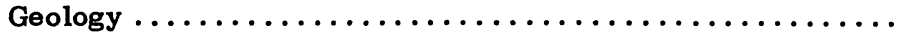

Ground water $\ldots \ldots \ldots \ldots \ldots \ldots \ldots \ldots \ldots \ldots \ldots \ldots \ldots \ldots \ldots$

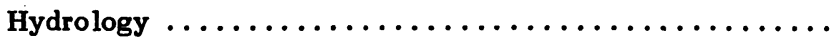

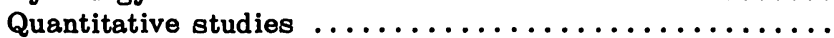

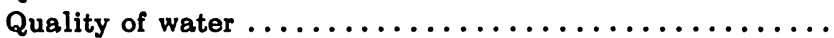

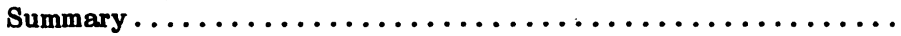

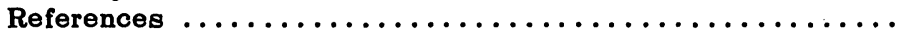

Well logs

\section{ILLUSTRATIONS}

Figure

1 Map of Florida peninsula showing location of Collier County and Immokalee area..$\ldots \ldots \ldots \ldots \ldots$.

2 Map and diagrams explaining well-numbering system .

3 Graph showing average monthly rainfall at Lake Trafford, for the period 1951-63, and monthly rainfall for $1963 \ldots \ldots \ldots \ldots \ldots \ldots \ldots \ldots \ldots \ldots \ldots$.

4 Map showing physiographic areas of Collier County..

5 Map showing location of inventoried wells, test holes, lines of lithologic logs, and wells sampled for chem-

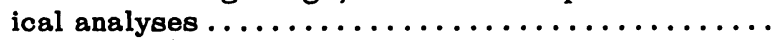

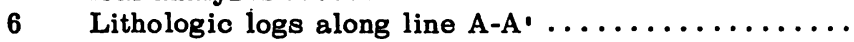

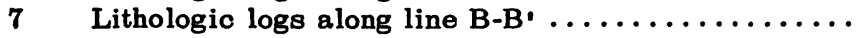

8 Fence diagram showing lithology of subsurface mat-

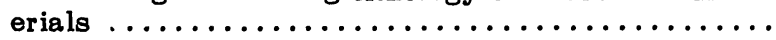

9 Graphs showing rainfall and stage at Lake Trafford

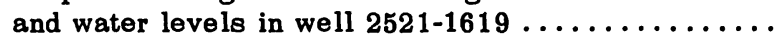
Bar graph showing concentrations of chemical constituents in ground water from selected wells in northwestern Collier County .................

11 Stiff diagrams showing relative concentrations of chemical constituents in ground water from wells....

\section{TABLES}

Table

1 Chemical analyses of water irom wells in the Immo- 



\title{
GROUND WATER IN THE IMMOKALEE AREA, COLLIER COUNTY, FLORIDA
}

\author{
By \\ Henry J. McCoy
}

\begin{abstract}
Potable ground water in the Immokalee area is available at depths ranging from about 20 to 300 feet below the land surface. The materials comprising this subsurface section are primarily quartz sand, marl, shells, and consolidated to semiconsolidated limestone. Although vertical and horizontal ground-water movement is retarded by marl layers, the section is essentially a single unconfined aquifer.

The principal chemical constituents of the ground water are calcium and bicarbonate. The most objectionable constituents are iron and hydrogen sulfide which occur in small amounts and both of which can be removed easily and inexpensively.

The shallow coarse sand and gravel beds west and northwest of Immokalee contain the best quality of ground water in the area and appear to be the most feasible source for municipal supplies. A deep limestone section in Immokalee and a shallow limestone section to the east could be developed for increased future demands. However, detailed studies regarding size, shape, and hydraulic characteristics of the major producing zones are needed to determine the overall ground-water potential of the system.
\end{abstract}

\section{INTRODUCTION}

\section{PURPOSE AND SCOPE}

Acceleration and expansion of farming in the Immokalee area, figure 1, during the past 10 years have caused rapid increases in both permanent and migrant labor populations. The accompanying demands for increased ground-water supplies and sewage disposal have been met by individual domestic wells and septic tanks. However, the concentration of population in the town of Immokalee and the increasing need for larger water supplies in the near future have made the need for a central water-supply system 


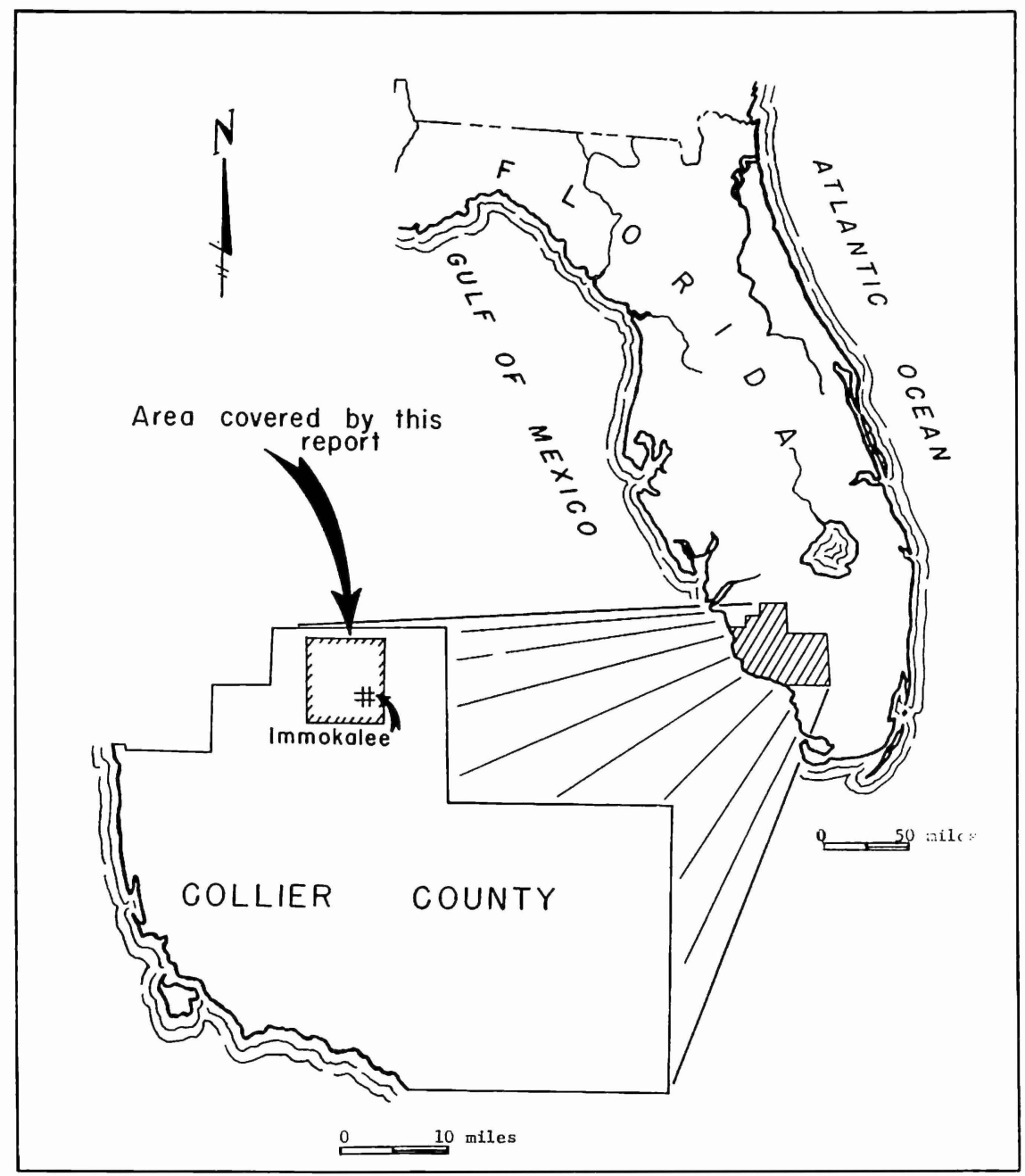

Figure 1. Location of Collier County and the Immokalee area.

apparent. Recognizing this, the Board of Commissioners of Collier County requested the U.S. Geological Survey to investigate the ground-water resources of the Immokalee area as a part of the continuing cooperative program started in 1958 between the County and the Survey. 
The scope of the investigation involved the drilling of test holes and the detailed inventorying of existing wells in order to define the location, depth, potential yield, and chemical quality of the water contained in the shallow aquifer that might be used for the development of a central water-supply system.

The field work and collection of data for the investigation covered the period 1961 through 1963. Much of the data collected for the report on the ground-water resources of Collier County (McCoy, 1962) is incorporated into this report.

The well-numbering system used in this report conforms with the well-numbering system of the Water Resources Division of the U.S. Geological Survey and is based on a one-second grid of parallels of latitude and meridians of longitude, figure 2.

The well number is a composite of two numbers separated by the letter $N$. The two numbers consist of the digits of the degrees, the two digits of the minutes, and the two digits of the seconds of latitude and longitude. The $\mathrm{N}$ indicates "North" latitude. If more than one well lies within a one-second grid, the wells are numbered consecutively and this number is placed at the end of the well number following the decimal. Hence, the well number defines the latitude and the longitude on the south and east sides of a one-second quadrangle in which the well is located.

Because the Immokalee area lies within the quadrangle formed by the $26^{\circ}$ north latitude parallel and the $81^{\circ}$ west meridian of longitude and each one-second quadrangle does not have more than one well, these digits, plus the letter $\mathrm{N}$, are deleted from the well numbers used in this report.

Therefore, well $262627 \mathrm{NO} 812601.1$ is referred to in the text as well 2627-2601.

\section{GEOGRAPHY}

\section{LOCATION AND GENERAL FEATURES}

Immokalee is an unincorporated community in the northern part of Collier County, Florida. (see fig. 1). Its principal occupations are truck farming and cattle raising. A large part of its 


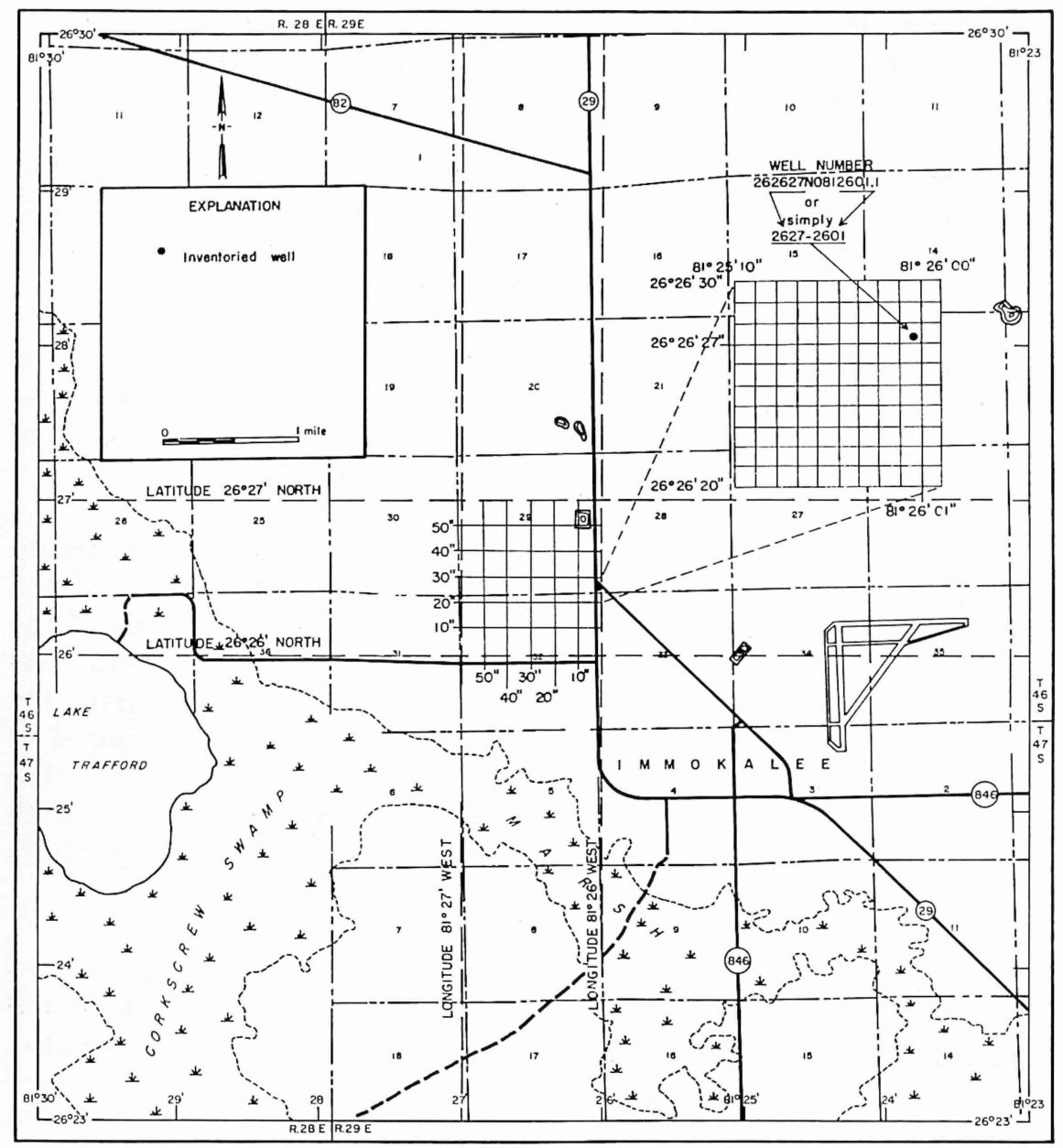

Figure 2. Well-numbering system.

1960 population of 4,800 was migrant farm laborers. Two main highways, State 846 and State 29, connect the town with surrounding communities. The town is serviced by bus and railway, and a small commercial plane airfield.

\section{CLIMATE}

The climate of Immokalee is subtropical with an average annual temperature of $76 \mathrm{oF}$. The warmest months are generally 
July and August. The average annual rainfall is 52 inches. More than half the yearly rainfall occurs during June through September. Figure 3 shows the average monthly rainfall at Lake Trafford, near Immokalee, for the period 1951-63 and monthly rainfall for 1963.

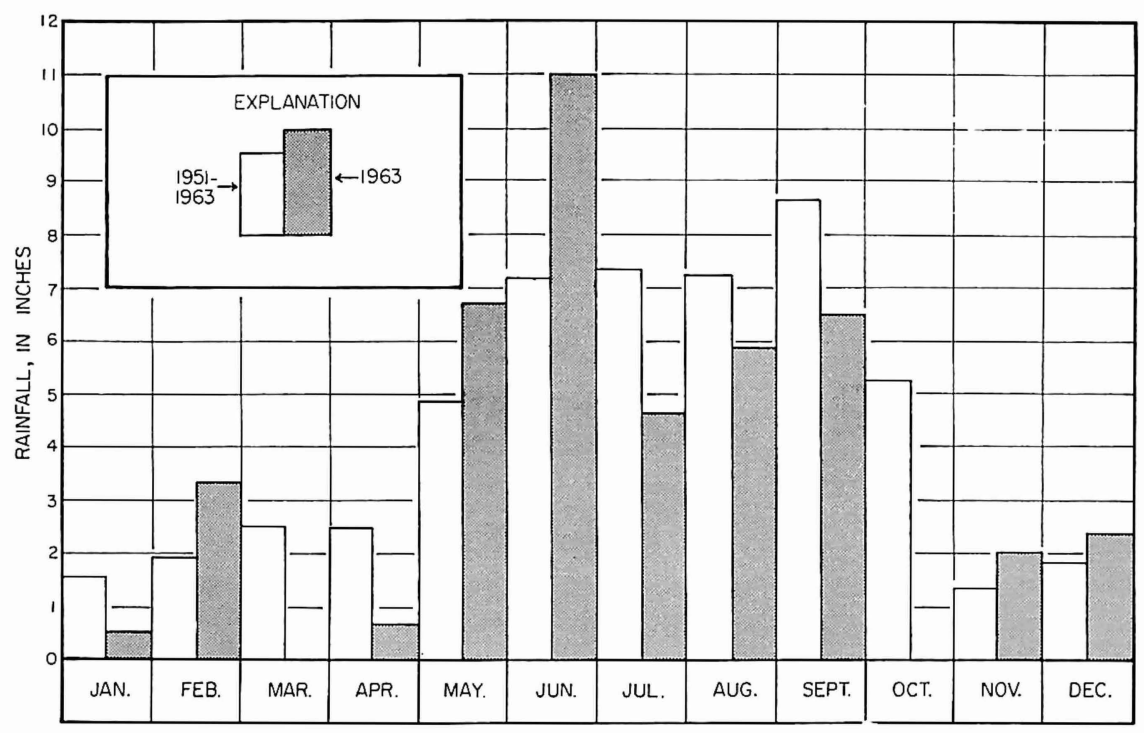

Figure 3. Average monthly rainfall at Lake Trafford, for the period 1951-63 and monthly rainfall for 1963 .

\section{TOPOGRAPHY AND DRAINAGE}

Immokalee is in the Flatlands physiographic area of Collier County as shown in figure 4 (Davis, 1943). The Flatlands is characterized by flat sandy areas, marshes, cypress stands, and openwater depressions. The elevation of the land surface is about 35 feet above msl (mean sea level). Except for high dunes on Marco Island (fig. 4), the highest elevations in the county, 42 feet, oc cur immediately north of Immokalee.

Drainage of the Immokalee area is generally westward toward Lake Trafford by way of sloughs and marshes, and southward through ditches and canals. Ditches and canals have improved the otherwise sluggish natural drainage. 


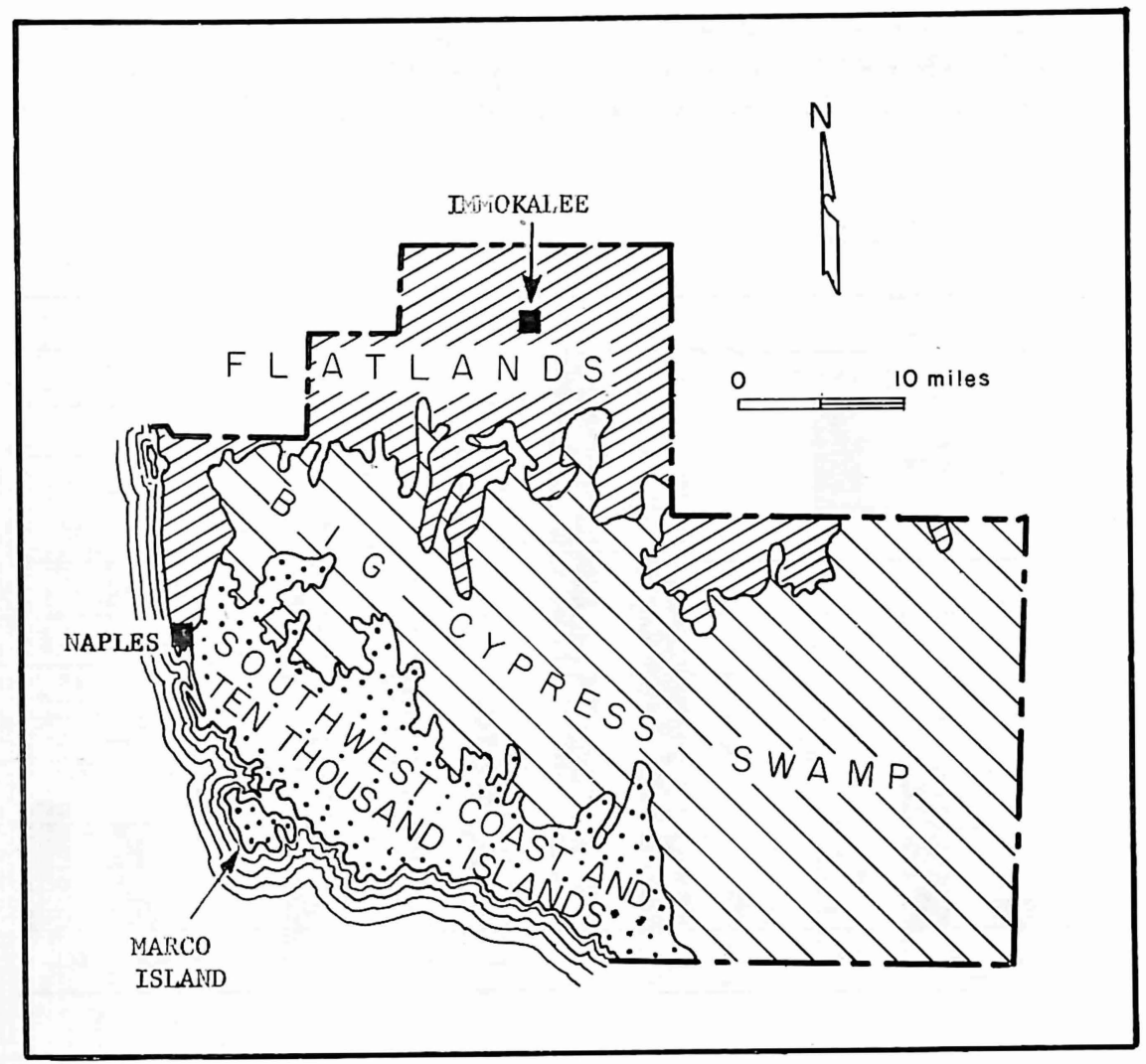

Figure 4. Physiographic areas of Collier County.

\section{WATER USE}

Ground water is the source of all irrigation and domestic supplies in the Immokalee area. Because the community does not have a central water-supply system and has little industry other than agriculture, the per capita use of water in the Immokalee area is probably about 50 to 75 percent of the national average of 150 gallons per day (Leopold and Langbein, 1960). Therefore, using 4,500 as the population for the period of investigation, an estimate of daily water use for the Immokalee area would be in the range of 0.3 to $0.5 \mathrm{mgd}$ (million gallons per day).

The principal crops grown in the Immokalee area are tomatoes, peppers, cucumbers, and watermelons and are irrigated by pumping 
ground water into ditches that dissect the fields. Estimates of water requirements for these crops are about .01 acre-foot $(3,250$ gallons per acre) per day (County Agent, personal communication). Assuming that an average of 5,000 acres were irrigated daily for the period of record, an estimate of daily water use for irrigation in the Immokalee area would be about $16 \mathrm{mgd}$.

\section{TEST-WELL DRILLING}

Three test holes were drilled in the Immokalee area during the countywide study but the location and extent of the major water-bearing formations in the Immokalee area could not be determined from this number of test holes. As a part of the present study, five additional test wells were drilled to depths of about 120 feet during the summer of 1961, as shown in figure 5. Rock cuttings and water samples were taken systematically during the drilling of each hole. Logs of the eight exploratory holes are given at the end of this report.

\section{GEOLOGY}

In the Immokalee area, the primary source of ground water is the permeable sediments in the uppermost 200 feet of the subsurface. This 200-foot section comprises mostly quartz sand, marl, shell beds, and consolidated and semiconsolidated limestone. The well logs in figures 6 and 7 and the lithologic fence diagram of figure 8 indicate that the materials change markedly with depth and location. Correlation between wells is extremely difficult because of the nonuniformity of sediments.

The materials in the lower 100 feet of the 200-foot section are probably of late Miocene age and are similar to the Tamiami Formation throughout most of Collier County, except for the absence of consolidated limestone. The gravel and coarse sand beds of the upper 100 feet of the 200-foot section of permeable sediments are somewhat unique to the Immokalee area and may have been deposited by large late Miocene and pre-Pleistocene deltaic streams that extended southward from the Highlands Ridge (Bishop, 1956, p. 26). The shape, size, and texture of the materials composing the gravel beds, plus the presence of fresh-water shells and marls suggest that they were deposited in a lagoon or delta. The rapid vertical and horizontal changes in occurrence of the gravel beds could be attributed to streams changing fre- 


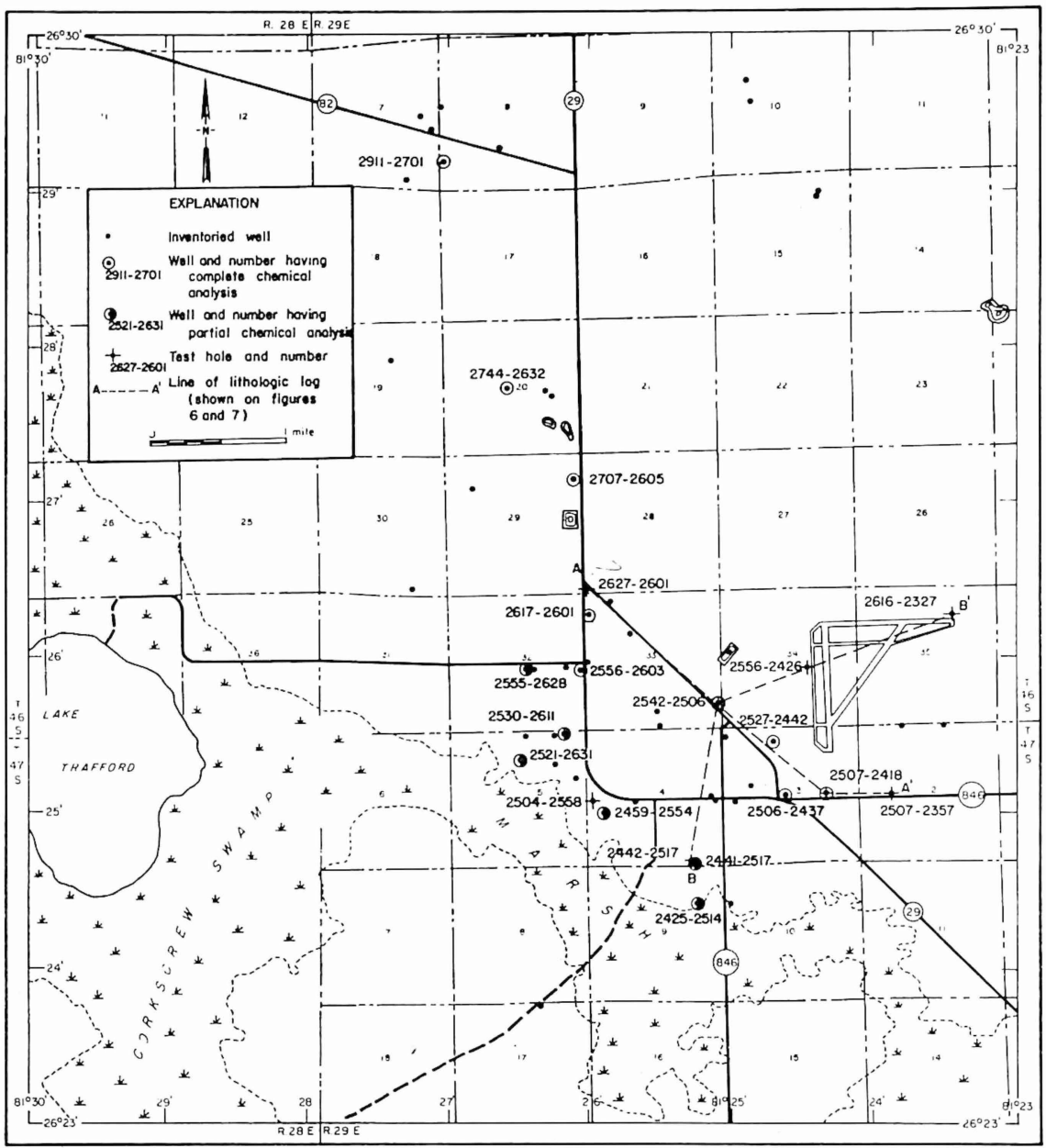

Figure 5. Location of inventoried wells, test holes, lines of lithologic logs, and wells sampled for chemical analyses. 


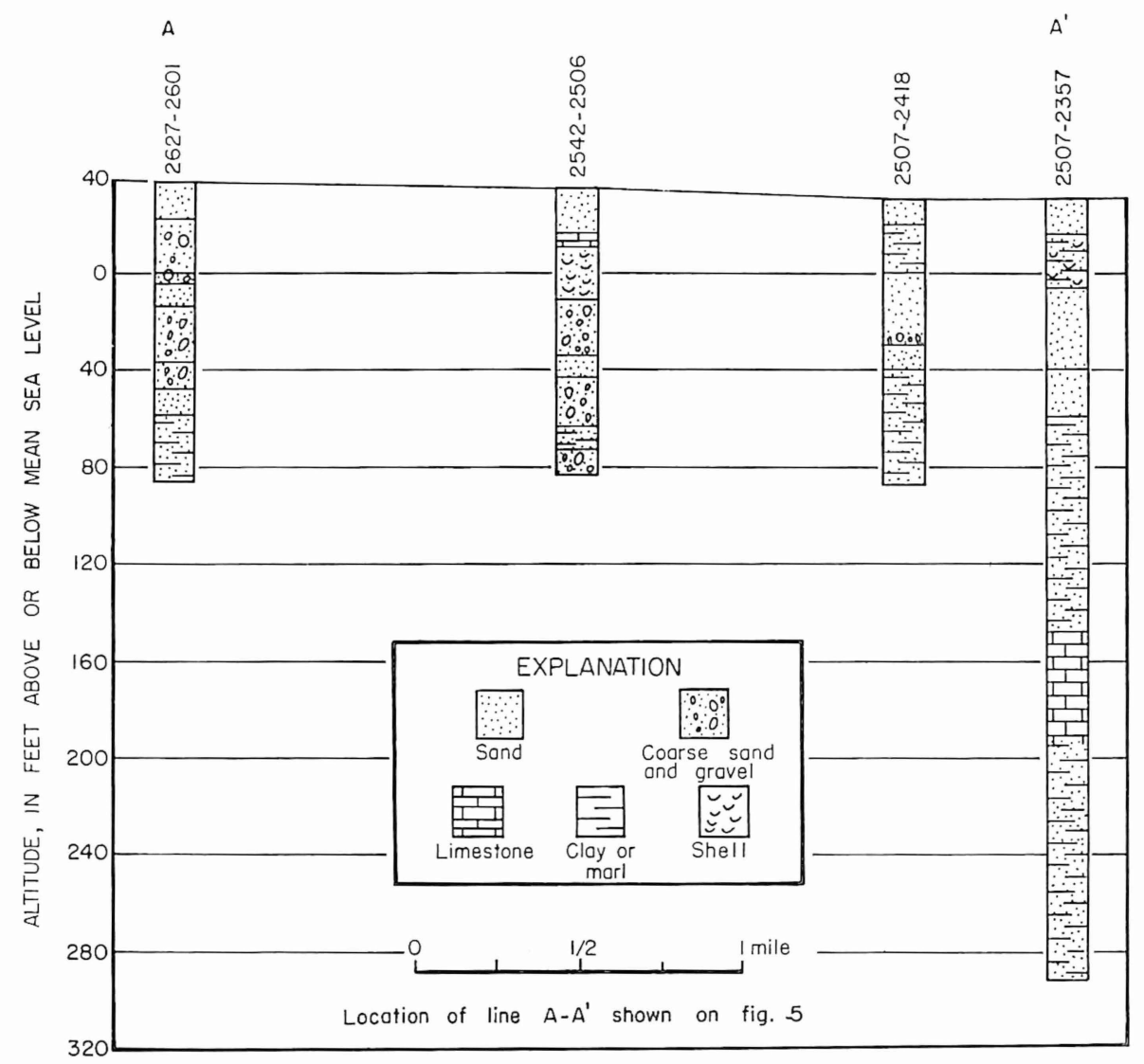

Figure 6. Lithologic logs along line A-A'.

quently on an ancient delta and to subsequent reworking of the deposits by wave action.

The surficial sands in the Immokalee area were deposited on the ocean floor during the Pleistocene Epoch when sea level was about 42 feet higher than at present. During a particular stand of the sea, the sands from rivers and streams settled in the shallow water near shore. These ancient sea floors are known as terraces and are recognizable throughout the Atlantic Coastal Plain. Although similar in composition to the surface sands in the Immo- 


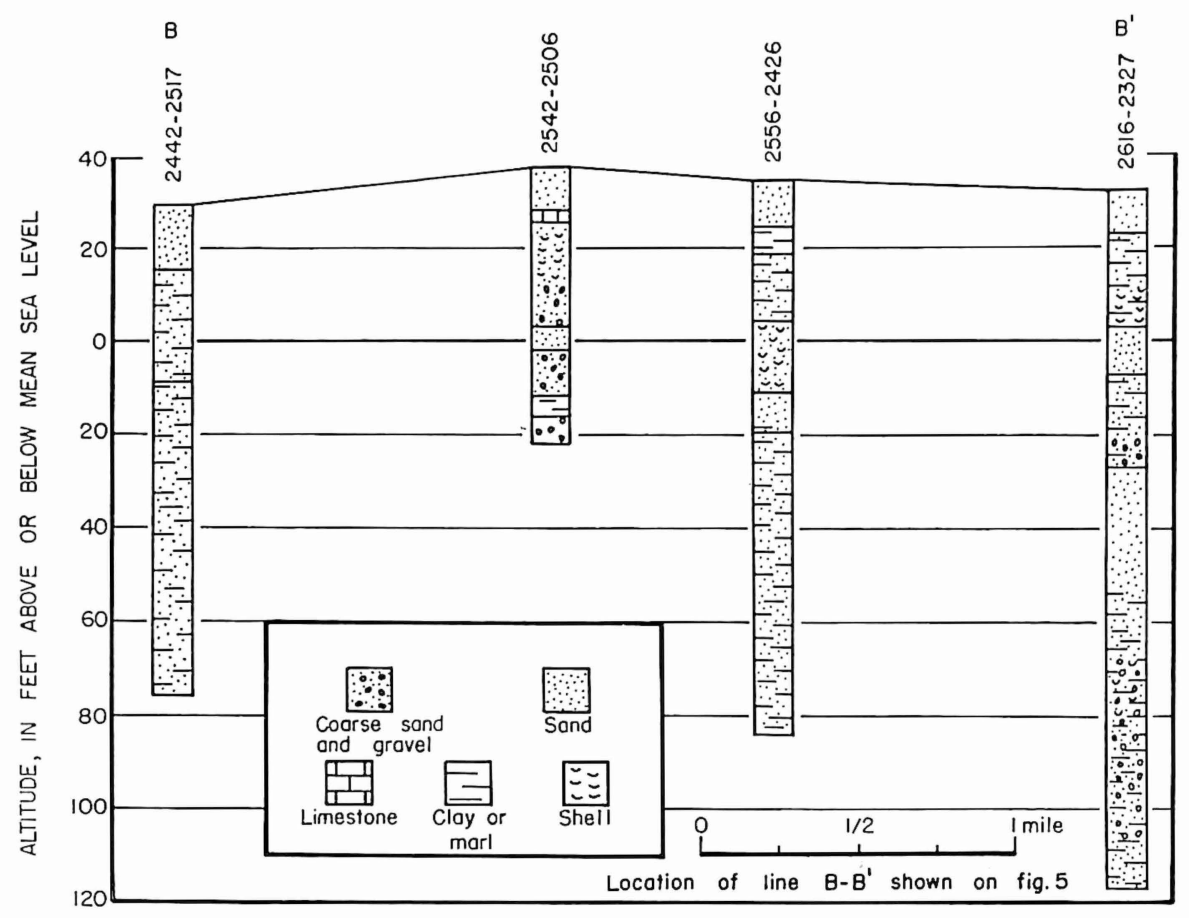

Figure 7. Lithologic logs along line B-B'.

kalee area, the surface sands throughout the rest of Collier County were deposited when sea level was only about 25 feet higher than at present.

Information from test drilling indicates that the limestone that occurs at shallow depths throughout the rest of the county pinches out as it approaches the Immokalee area from the southwest, south, and east.

\section{GROUND WATER}

Ground water occurs in permeable subsurface formations called aquifers. If the ground water is unconfined and under atmospheric pressure, its upper surface is called the water table. The slope of the water table indicates the direction of movement of unconfined ground water. Unconfined, or nonartesian aquifers are replenished by the downward infiltration of rainfall, or by 


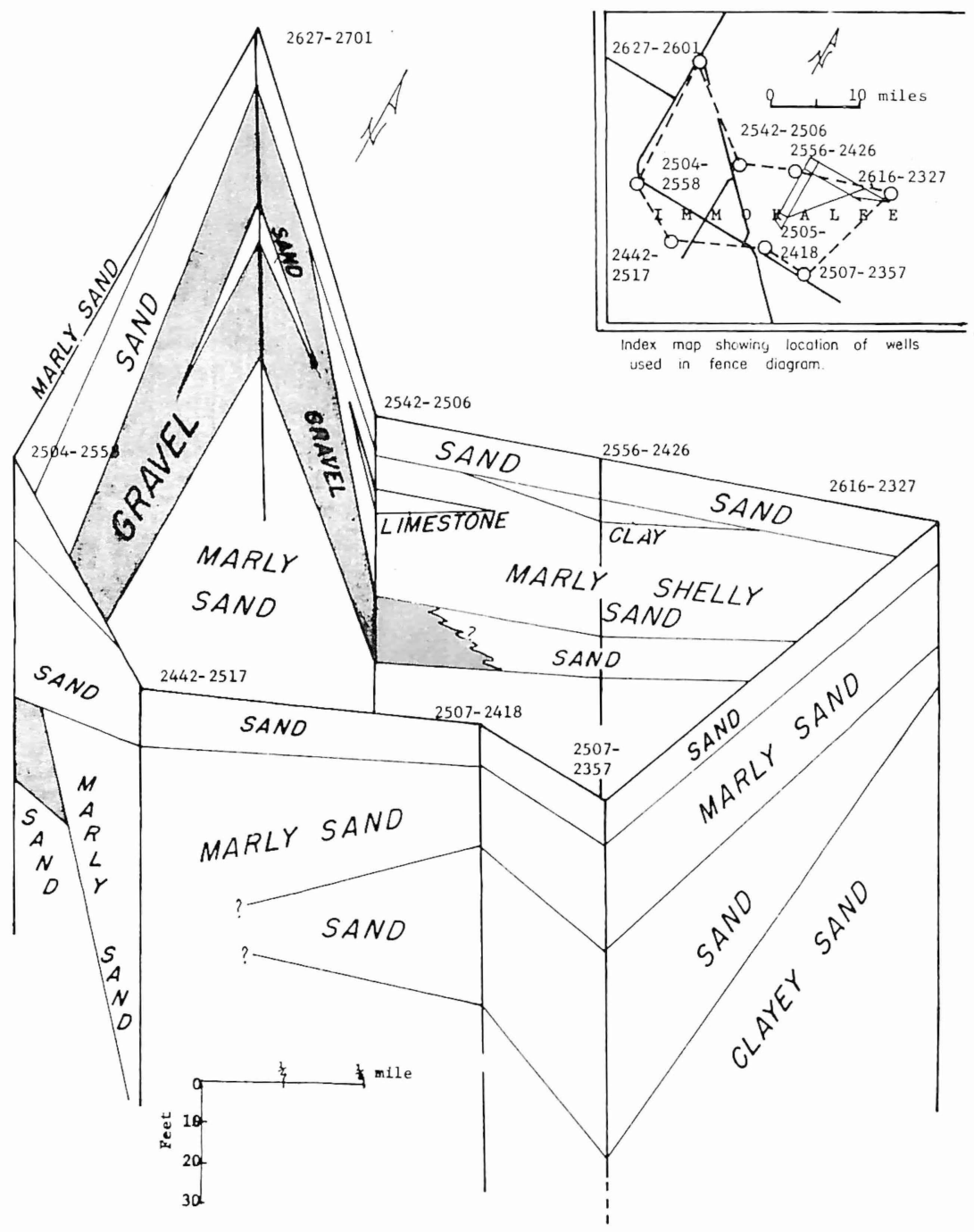

Figure 8. Lithology of subsurface materials. 
downward seepage from lakes and rivers. This replenishment, or recharge, generally occurs in varying degree throughout the extent of the aquifer.

Data from test holes in the Immokalee area indicate the ground water to a depth of nearly 300 feet is unconfined or partly confined. The presence of marl beds throughout the section suggests that partly confined conditions may exist in areas where the marl beds of low permeability separate the water-bearing zones on the top and bottom. However, the partly confined zones appear to be of limited areal extent and therefore have little significance as large water-bearing reservoirs.

Domestic and industrial wells in the Immokalee area range in depth from 22 to 292 feet below the land surface. Large establishments such as the packing houses usually obtain groundwater supplies from consolidated materials at depths greater than 150 feet.

Fifteen or more years ago, large quantities of ground water for irrigation were derived from the artesian Floridan aquifer which underlies the Immokalee area at a depth of about 400 feet (McCoy, 1962 , p. 18). However, because the artesian water is highly mineralized, smaller wells developed in the shallow aquifer have replaced nearly all of the deep artesian wells. Many of the remaining artesian wells are still serviceable and could be used as a supplemental source to mix with the shallow ground-water supplies during droughts.

Because the Floridan aquifer contains tremendous quantities of water, it should not be ignored because of its mineralization. As domestic and agricultural demands for ground water increase in the future, the importance of the artesian aquifer as a potential source of ground water will also increase.

\section{HYDROLOGY}

In the Immokalee area, surface-water bodies are directly connected to the shallow aquifers. Levels of lakes and canals reflect essentially the elevation of the water table.

The shallow aquifer in the Immokalee area is recharged principally by local rainfall. During the rainy season some of the 
higher parts of the county north of Immokalee are inundated and overland and groundwater flow enter the area to recharge the aquifer.

Canal flow and evaporation from open bodies of water are the principal means of surface-water discharge in the Immokalee area and are greatest during the rainy season.

Irrigation, evapotranspiration, and domestic use are the principal means of ground-water discharge. The significance of irrigation discharge is more pronounced during the dry winter months when farming is at a maximum.

In the Immokalee area the water level fluctuates in response to rainfall, evapotranspiration, and pumping. Figure 9 shows hydrographs of daily rainfall and stage at Lake Trafford and a well 54 feet deep, 8 miles east of Immokalee. The fluctuations of the lake stage and the water level in the well are similar. Both levels rise in response to increased rainfall and fall during decreased rainfall. The "saw-tooth" pattern of fluctuations of water levels in the well is due primarily to nearby irrigation wells being pumped periodically. The hydrographs show that the range of fluctuation of the water levels in 1963 was about 4 to 5 feet and probably reflect the range of the water-table fluctuation throughout most of the area. Some outlying areas around Immokalee are drainedby canals to reduce flooding thereby preventing large fluctuations of the water table.

The subsurface material changes markedly in short distances and with depth; these differences result in changes in both horizontal and vertical permeability. In the area northwest of Immokalee, shallow (50-foot) irrigation wells pumping at $150 \mathrm{gpm}$ (gallons per minute) produce drawdowns of about 5 feet or more, while in the area east of Immokalee, wells of similar depths (51 and 54 feet) discharging $1,000 \mathrm{gpm}$ produce equal or less drawdown. This is due chiefly to the differences in aquifer permeability. Wells in the eastern area penetrate a limestone of very high permeability, while those in the northwestern area tap sandy materials of much lower permeability.

\section{QUANTITATIVE STUDIES}

To determine the ground-water potential of an area, the hydraulic properties of the aquifers must be known. The principal 

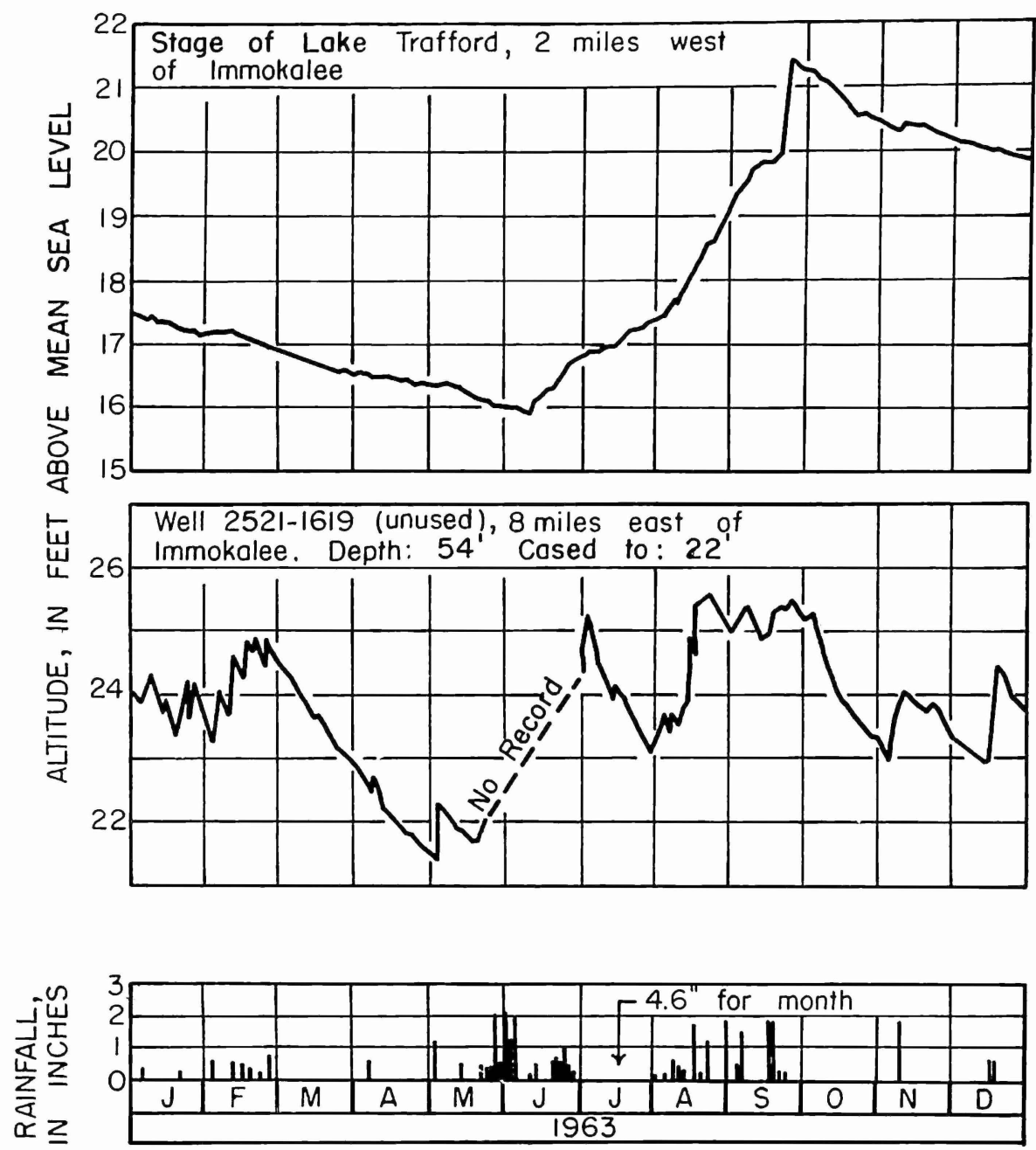

Figure 9. Rainfall and stage at Lake Trafford and water levels in well 2521-1619.

hydraulic properties of an aquifer are its capacities to transmit and store water. If less permeable beds are present above or below the aquifer, leakage through those beds is also important to the overall potential of the hydraulic system. The aquifer properties are generally expressed as coefficients of transmissibility, storage, and leakance. The most commonly used method for determining these properties is by an aquifer test wherein a well penetrating the aquifer is pumped and its effect on the water table is observed in other wells in the vicinity of the pumped well. 
The coefficient of transmissibility $(\mathrm{T})$ is a measure of the capacity of an aquifer to transmit water. In customary units it is the quantity of water that will flow through a vertical section of the aquifer 1-foot wide and extending the full saturated height, under a unit hydraulic gradient, at the prevailing temperature of the water (Theis, 1938, p. 892). The coefficient of storage (S) is a measure of the capacity of an aquifer to store water and is defined as the volume of water released from or taken into storage per unit surface area of the aquifer per unit change in the component of head normal to that surface. The coefficient of leakance characterizes the ability of semiconfining beds above or below an aquifer to transmit water to the aquifer (Hantush, 1956, p. 702). It is defined as the quantity of water that crosses a unit area at the interface between the main aquifer and its confining bed, if the difference between the head in the main aquifer and in the beds supplying the leakage is unity.

Two tests were made in the Immokalee area. The locations of the tests were determined by the availability of wells penetrating the aquifer that could be used for pumping and for observing fluctuations of the water table. The site of the first test was about 8 miles east of Immokalee at the Collier County line (Klein and others, 1962). A large diameter irrigation well was pumped at a rate of $1,300 \mathrm{gpm}$ for 25 hours. Analyses of the data from the observation wells indicated that $\mathrm{T}$ was $960,000 \mathrm{gpd} / \mathrm{ft}$ (gallons per day per foot), $\mathrm{S}$ was 0.00031 , and the coefficient of leakance was $0.0000011 \mathrm{gpd} / \mathrm{sq} \mathrm{ft} / \mathrm{ft}$ (gallons per day per square foot per foot of vertical head) of vertical head.

The second test was made at an abandoned farm about 5 miles northwest of Immokalee. A 6 -inch well was pumped at a rate of $152 \mathrm{gpm}$ for 44 hours. Values for $\mathrm{T}, \mathrm{S}$, and leakance were: $60,000 \mathrm{gpd} / \mathrm{ft}, 0.00025$, and $0.00086 \mathrm{gpd} / \mathrm{sq} \mathrm{ft} / \mathrm{ft}$ of vertical head, respectively.

The differences in values of the coefficients for the two sites are due to differences in lithology in the two areas. The principal aquifer in the area east of Immokalee is composed of highly permeable solution-riddled limestone which exceeds 35 feet in thickness. This accounts for the large value of $T$. The limestone section is overlain by 5 feet of surficial, mediumgrained sand and 17 feet of sandy clay which retards downward leakage. On the other hand, the aquifer northwest of Immokalee 
which is composed chiefly of sand, is considerably less permeable than the limestone aquifer, but it receives a larger amount of recharge by vertical leakage. This is probably because the overlying sands in the northwestern area contain less marl and therefore are more permeable than the overlying materials in the eastern area.

Of the five wells inventoried that are reported to be finished in the gravel and coarse sand beds, three are used for farm irrigation. No detailed pumping data are available for the three wells but personal communications with the farmers indicated that the wells are pumped between 750 and $1,000 \mathrm{gpm}$ for varying periods each day with 10 feet or less drawdown of the water table near the pumped well. If additional test drilling indicates the gravel and coarse sand beds to be thick and continuous over a widespread area it appears these beds would be adequate to furnish ground-water supplies to a municipal system for present water requirements. However, aquifer tests would be required to determine optimumi spacing and discharge of wells to meet present and near future demands.

\section{QUALITY OF WATER}

The chemical composition of ground water in an area is determined principally by the type of water which recharges the aquifer, the character of the geologic materials through which the water passes, the duration of contact and chemical reaction between the water and rock, and the effects of human activity. Most public drinking-water supplies in the United States strive to conform to standards established by the U.S. Public Health Service for water used on interstate carriers. Below are some of the more common chemical constituents and properties and the maximum amounts recommended by the U.S. Public Health Service (1961) in parts per million:

Alkyl benzene sulfonate (detergents) $\ldots \ldots \ldots \ldots \ldots \ldots \quad 0.5$

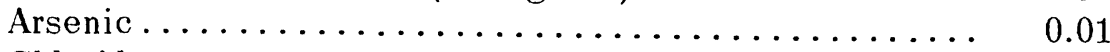

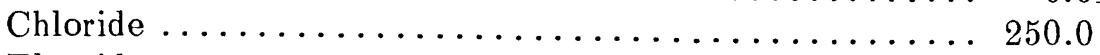

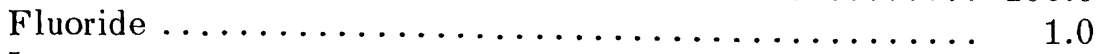

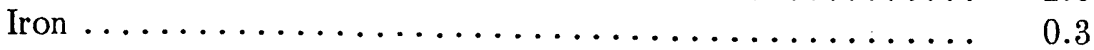

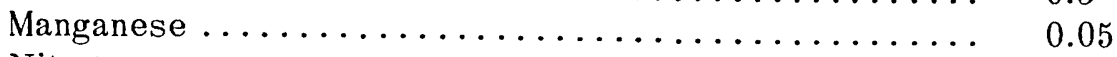

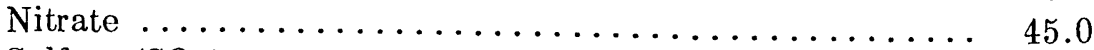

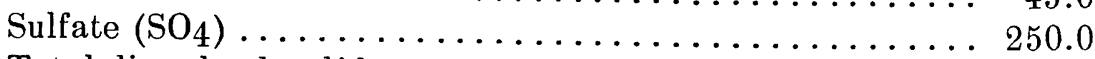

Total dissolved solids................. 500.0 
Iron in concentrations greater than that listed above is objectionable because it imparts a disagreeable taste and it quickly discolors objects with which it comes into contact. Its presence in ground water in the Immokalee area is unpredictable as to depth and location. Fortunately, iron can be removed easily by aeration and filtration.

Hardness is a measure of the calcium and magnesium content of ground water and is customarily expressed as the equivalent of calcium carbonate. Water having a hardness less than $60 \mathrm{ppm}$ (parts per million) is rated as soft; 60 to $120 \mathrm{ppm}$, as moderately hard; and more than $120 \mathrm{ppm}$, as hard. Water having a hardness of more than $200 \mathrm{ppm}$ ordinarily requires softening for most uses.

The $\mathrm{pH}$ indicates the acidity or alkalinity of water. The $\mathrm{pH}$ scale ranges from 0 to 14 . A pH value of 7 indicates neutral water; values less than 7 denote increasing acidity, and those greater than 7 denote increasing alkalinity.

Water samples from 16 wells were analyzed to determine the quality of water in the Immokalee area, as shown in figure 10. Complete chemical analyses were made on 10 of the samples and determinations of selected constituents were made on the remaining 6 samples. The results of the analyses are given in Table 1 . The depths of the 16 wells range from 22 to 292 feet below the land surface. The wells are used for domestic, industrial or public supplies, and for irrigation.

The bar graph in figure 10 shows the concentration of six important chemical constituents in the ground water from 10 locations in the Immokalee area. Analyses of water from four other locations in Collier County are included for comparison.

The constituents in Table 1 are expressed in parts per million. This compares the concentrations of constituents in solution by weight. Equivalents per million is used in figure 10 and takes into account not only weight concentrations but also the concept of chemical equivalence. Expressing concentrations in equivalents per million means the constituents are also chemically equivalent. When all constituents have been determined, the total equivalents on one side of the bar in the bar graph should very nearly equal the equivalents on the other side of the bar (Hem, 1959). 


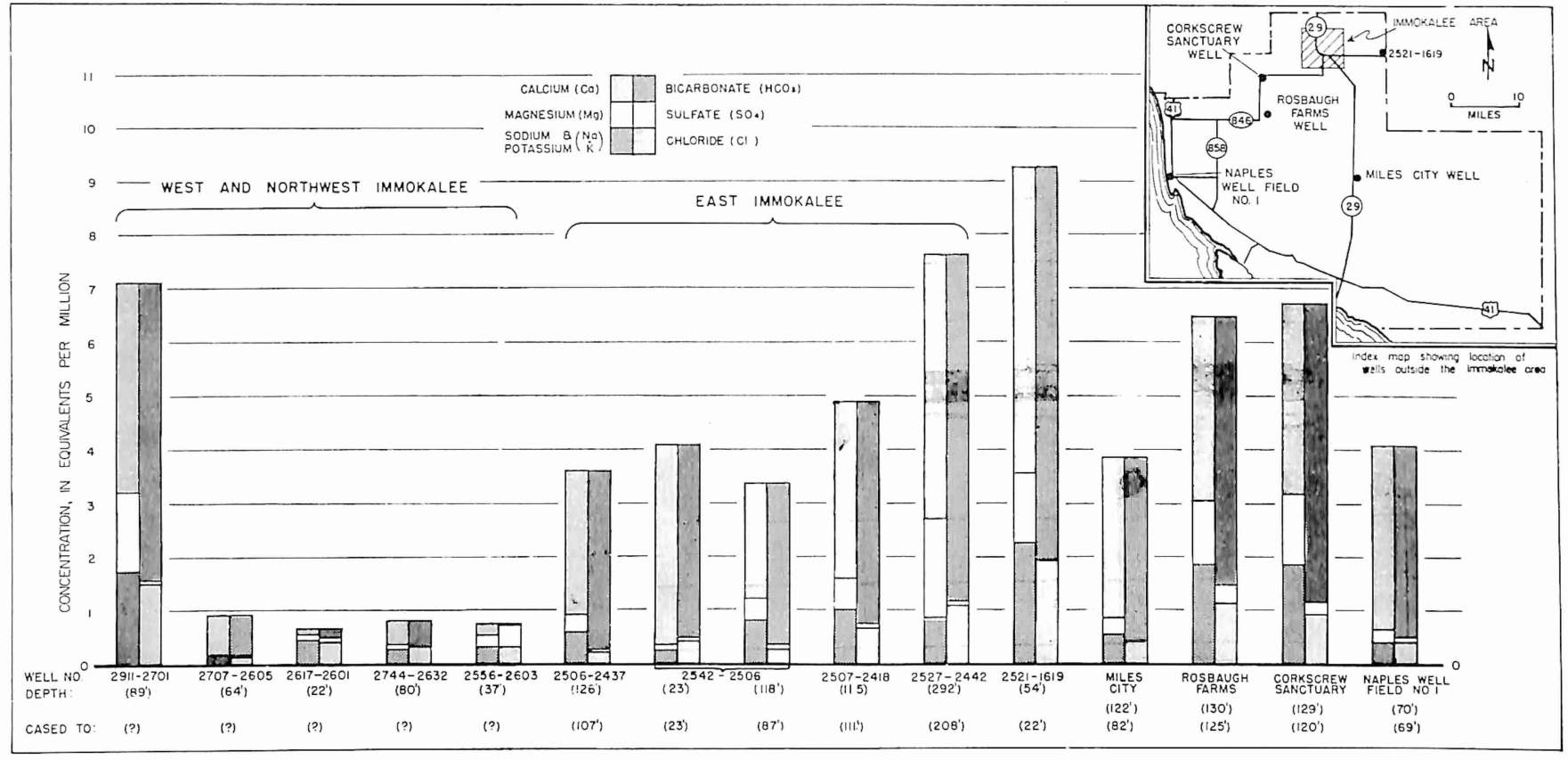

Figure 10. Bar graph showing concentrations of chemical constituents in ground water from selected wells in northwestern Collier County. 
Table 1.--Chemical analyses of water from wells in the Immokalee area.

(Results in parts per million except those for color, $\mathrm{pH}$, and specific conductance) (Analyses by U. S. Geological Survey)

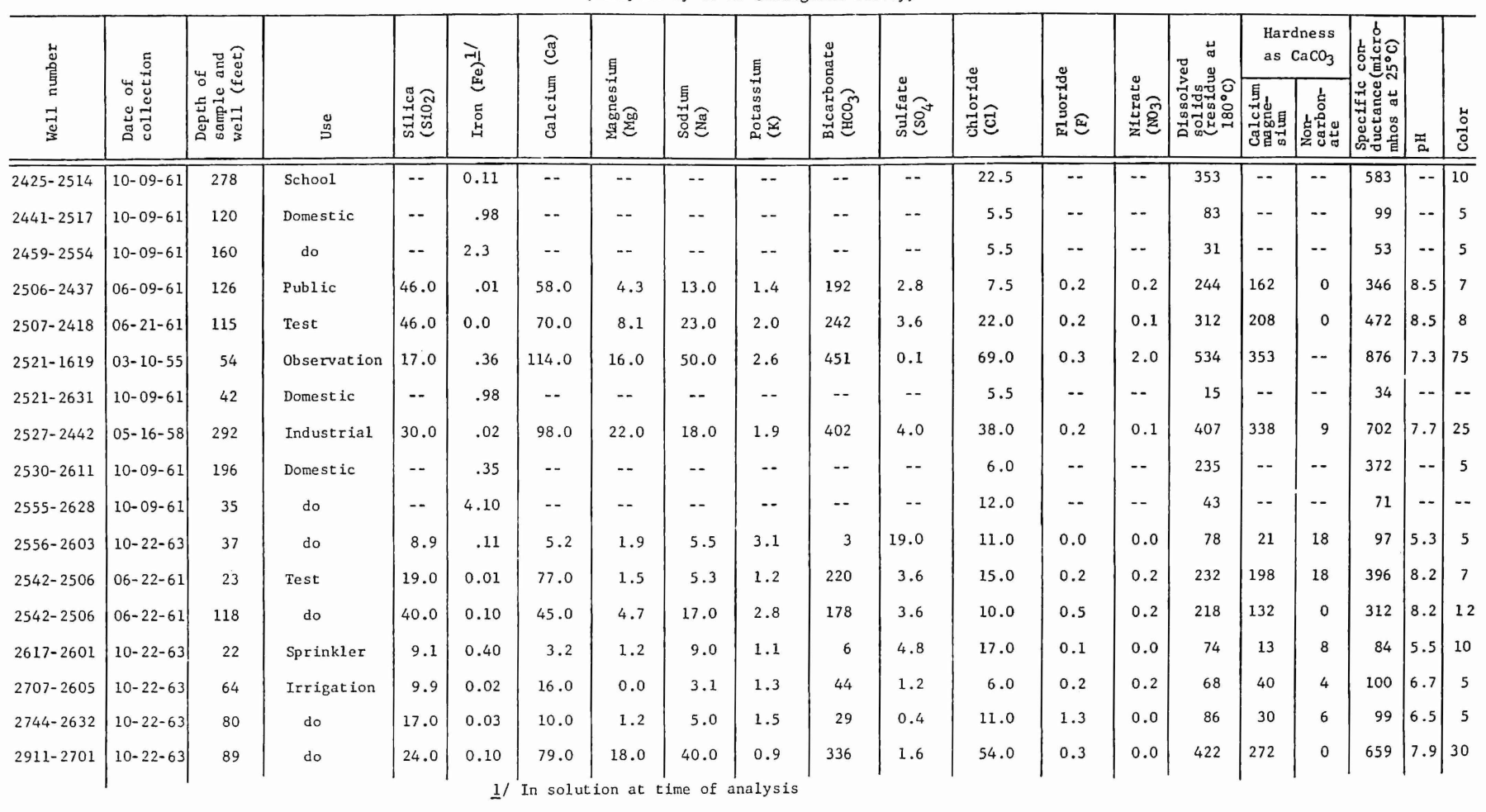


The five wells in the western and northwestern parts of the Immokalee area (2911-2701, 2707-2605, 2617-2601, 2744-2632, and 2556-2603) are reported to be finished in gravel beds ranging in depth from 22 feet to 89 feet. However, the chemical content of the water from well 2911-2701 (41/2 miles northwest of Immokalee) (fig. 10) appears to be similar to that of well $2527-2442(1 / 4$ mile southwest of airfield) which is finished in limestone. Well 25211619 , 54-feet deep, located about 8 miles east of Immokalee (see fig. 10), draws water from the highly permeable shallow limestone. This probably accounts for the large amount of dissolved solids, chiefly calcium bicarbonate, in the water sample. Well 2527-2442 furn ishes industrial water supplies for a large packing house in Immokalee. The well is finished in a sandy, poorly-consolidated limestone at a depth of 292 feet.

Figure 11 illustrates with more clarity any differences in water quality between wells of various depths in the Immokalee area. Each diagram was constructed by determining the percentage of a constituent to the total concentration of each group of constituents; for example, the value for calcium was determined by dividing its concentration by the total concentration of calcium magnesium, and sodium-potassium. The same procedure was used for the right side of each diagram.

Water of good quality is represented in figure 11 by a diagram which has a broad top and a narrow base. Wells 2542-2506, 27072605 , and 2506-2437 are examples of this characteristic. The diagrams make it obvious that the primary constituents in the water from all but two of the wells are calcium and bicarbonate. The diagrams do not account for differences in total dissolved solids between water samples. For example, water from wells 2556-2603 and 2617-2601 contain primarily sodium-potassium and chloride and appear to have considerably larger amounts of these constituents than do the other waters. However, the chloride content of well $2556-2603$ is 11 ppm and that of well $2542-2506$ is $15 \mathrm{ppm}$. This is because well $2542-2506$ has about 3 times as much total dissolved solids as does well 2556-2603.

The abnormal diagrams for wells 2556-2603 and 2617-2601 must be attributable to some factor other than shallow depth. Well 2542-2506 is similar in depth to wells 2556-2603 and 2617-2601 yet its diagram is comparable to the majority of the other wells. Well 2542-2506 is finished in a sandy limestone overlain by essen- 
WELL $2556-2603$

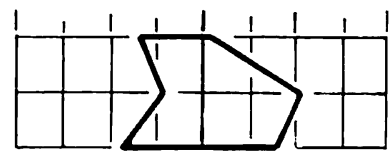

DISSOLVED SOLIDS $=78$

TOTAL DEPTH $=37^{\circ}$

WELL 2542-2506

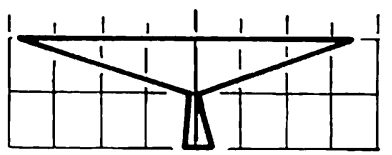

DISSOLVED SOLIDS $=232$

TOTAL DEPTH $=23^{\prime}$

WELL 2707-2605

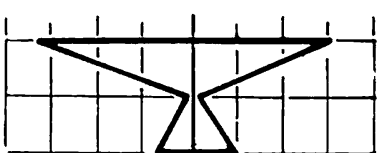

DISSOLVED SOLIDS $=40$

TOTAL DEPTH $=64^{\prime}$

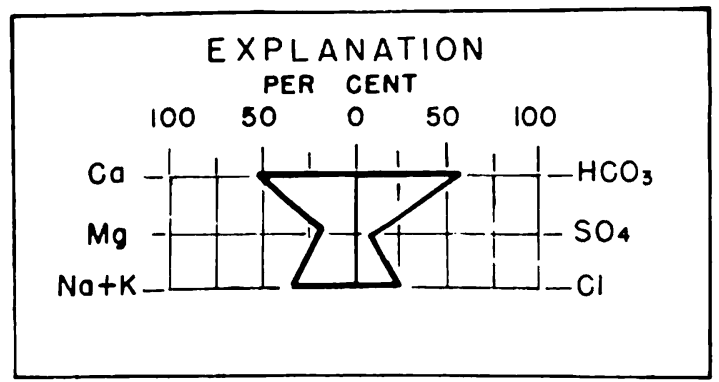

WELL 2521-1619

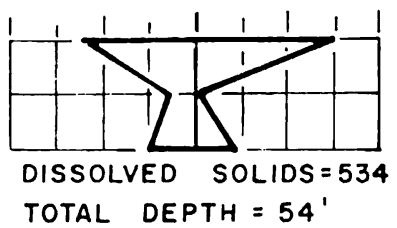

WELL 2617-2601

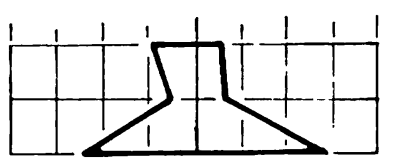

DISSOLVED SOLIDS $=74$

TOTAL DEPTH $=22^{\circ}$
WELL 2506-2437

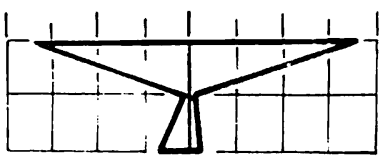

DISSOLVED SOLIDS $=244$

TOTAL DEPTH $=126$

WELL $2507-2418$

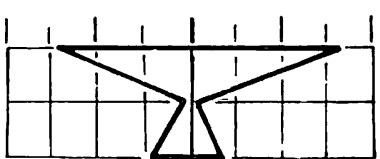

DISSOLVED SOLIDS $=312$

TOTAL DEPTH $=105^{\circ}$
WELL $2744-2632$

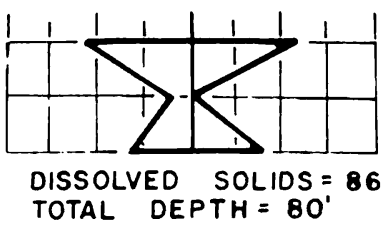

WELL $2542-2506$

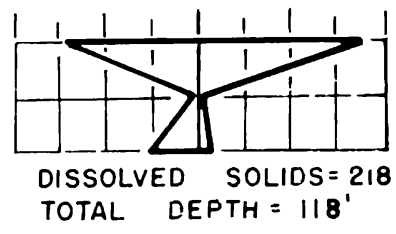

WELL 2911-2701

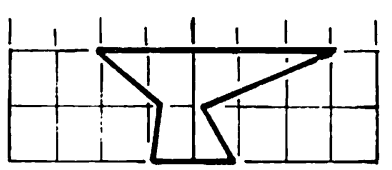

DISSOLVED SOLIDS $=422$

TOTAL DEPTH $=89^{\circ}$

Figure 11. Stiff diagrams showing relative concentrations of chemical constituents in ground water from wells. 
tially clear sand. Wells 2556-2603 and 2617-2601 are reported to be finished in the gravel and coarse sand beds overlain by highly organic sands and marls. Leaching of these organic zones by downward filtering rainwater may be the cause of higher concentrations of sodium, potassium, and chloride in the two wells.

Table 1 and figure 10 indicate that water from all wells sampled is chemically suited for domestic use, but the water in the gravel and coarse sand beds in the western and northwestern part of the area would require the least treatment for use as a municipal supply. However, available data are insufficient to determine accurately the areal extent, thickness, and water-bearing characteristics of these beds. If a municipal supply is to be established in Immokalee, more detailed test drilling and aquifer tests are needed there to determine the hydraulic characteristics of the individual lithologic types. Because of the satisfactory quality of the water, the shallow depth, and close proximity to the town, the gravel and coarse sand beds appear to be the most feasible aquifer to develop. If testing proves the beds to be too localized and the needed quantity of water cannot be obtained, the gravel and sand beds and the deep limestone aquifer may be utilized as a dual source. The permeable shallow limestone to the east can be utilized to meet future demands.

\section{SUMMARY}

Potable ground water is available throughout the Immokalee area to a depth of about 300 feet. The subsurface materials are primarily quartz sand, consolidated and semiconsolidated limestones, marl, and shell beds, and can be considered as a single unconfined aquifer. However, because individual layers are, for the most part, discontinuous both vertically and horizontally, there may be areas where the aquifer is confined and where yields may be low.

The principal chemical constituents in the ground water are calcium and bicarbonate. The difference in mineral composition within the aquifer seems to be the chief reason for the difference in quality of the water between locations. The ground water of the sand and gravel sections in the western and northwestern part of the Immokalee area contains from 40 to $232 \mathrm{ppm}$ of dissolved solids, as compared to $534 \mathrm{ppm}$ for the limestone section east of 
the area. Iron and hydrogen sulfide are the most objectionable constituents in the ground water, but they can be removed easily and inexpensively by simple aeration.

The gravel and coarse sand in the western and northwestern part of the area varies in depth from 22 feet to 80 feet and appears to be the most feasible source to be developed for present municipal water supply needs. However, more detailed test drilling and aquifer tests will be required to fully determine size, shape, and water-bearing potential of the formation. In the future, much larger supplies could be developed from the deeper limestone section in Immokalee or the shallow permeable limestone to the east. 



\section{RE FERENCES}

Bishop, E.W.

1956 Geology and ground-water resources of Highlands County, Florida: Florida Geol. Survey Rept. Inv. 15.

Davis, J.H.

1943 The natural features of southern Florida, especially the vegetation and the Everglades: Florida Geol. Survey Bull. 25.

Hantush, M.C.

1956 Analysis of data from pumping tests in leaky aquifers: Am. Geophys. Union Trans., v. 37, no. 6, p. 702-714.

Hem, J.D.

1959 Study and interpretation of the chemical characteristics of natural water: U.S. Geol. Survey Water-Supply Paper 1473.

Klein, Howard

1962 (and others) Geology and ground-water resources of Glades and Hendry Counties, Florida: Florida Geol. Survey Rept. Inv. 37.

Leopold, L.B.

1960 (and Langbein, W.B.), A Primer on water: U.S. Geol. Survey.

McCoy, H.J.

1962 Ground-water resources of Collier County, Florida: Florida Geol. Survey Rept. Inv. 31 .

The is, C.V.

1938 The significance and nature of the cone of depression in ground-water bodies: Econ. Geology, v. 33, no. 8, p. 889-902.

U.S. Public Health Service

1961 Drinking water standards: Am. Water Works Jour., v. 53, no. 8, p. 939-945. 

INFORMATION CIRCULAR NO. 51

\section{APPENDIX}

Well Logs 

Well 2442-2517

\section{Material}

Sand, quartz, fine to medium, brown

Sand, quartz, fine to medium, grayish; marly

Sand, quartz, coarse, gray; phosphorite; marly

Sand, quartz, coarse, brownish gray; phosphorite; marl increasing

Sand, quartz, medium to coarse, light gray; little marl

Sand, quartz, fine to medium, light gray; marl increasing

Sand, quartz, fine to medium, light gray; phosphorite; little marl
Depth, in feet below land surface

$0-14$

$14-38$

$38-68$

$68-72$

$72-90$

$90-93$

$93-104$

Well 2504-2558

Sand, quartz, fine to medium, buff to gray; little marl

Sand, quartz, fine, tan $20-40$

Sand, quartz, medium to coarse, tan 40-60

Gravel, quartz, well-rounded, brown to gray; some clay

Sand, quartz, very coars e, smooth, well-rounded, large amount of phosphorite

Sand, quartz, medium, dark brown, organic material

Sand, quartz, medium, dark brown, organic; marly; phosphorite in lower part

Sand, quartz, fine, light gray, marly; phosphorite in lower part

Sand, quartz, fine, gray; becoming coarser in lower part

Sand, quartz, fine

Sand, quartz, very fine, light gray; phosphorite

Sand, quartz, fine to medium, gray; phosphorite; clay, bluish-green

Clay, green, phosphatic; sand, quartz, fine

Clay, green, phosphatic; sand, quartz, coarse 


\section{Material}

Well 2507-2357

Sand, quartz

Sand, calcareous, light brown, thin layer of shell

at 18 feet

Depth, in feet below land surface

Sand, quartz, medium gray

Sand, quartz, large amount of clay; greenish-gray

Sand, quartz, medium coarse, gray to green

Sand, quartz, medium gray, and clay, green

Limestone, white, sandy

Clay, sandy, calcareous, gray to green

$212-290$

Clay, green, phosphatic, pebble-size sand

290-303

Well 2542-2506

Sand, quartz, dark brown, organic

Sand, quartz, fine to medium, white to gray, marly, shelly

Limestone, buff to gray, poorly consolidated; low permeability

Sand, quartz, medium, gray, shelly

Gravel, quartz, well-rounded, smooth; some limestone and clay in lower part

Sand, quartz, fine to medium, clayey

Sand, quartz, medium, with intercalated clay lenses

Sand, quartz, coarse, highly phosphatic

Well 2556-2426

Sand, quartz, organic

Clay, bluish-green

Sand, quartz, fine, phosphatic, shelly, calcareous

Sand, quartz, fine to coarse, some grains rose colored; phosphorite, shells, calcareous

Sand, quartz, very fine to fine, clayey at bottom

Sand, quartz, coarse, gray

Sand, quartz, fine; clay, green, becomes blue at bottom

Sand, quartz, fine to medium; clay, bluish; shells; phosphorite 
Material

Well 2616-2327

Sand, quartz, medium, brown, marly; organic material

Sand, quartz, medium, light brown, shelly, marly; becomes very shelly in lower part

Sand, quartz, very fine, gray, phosphatic

Sand, quartz, coarse, gray, clayey, phosphatic; contains corals; sand becomes pebble-size in lower part

Sand, quartz, very fine, light gray, phos phatic, becomes coarser and contains dark green marl in lower part

Sand, quartz, coarse to pebble-size; sandstone; shell fragments; clay, marly, dark green

Sand, quartz, coarse to pebble-size; clay, marly, green

Sand, quartz, very fine, gray, marly, clayey, phosphatic

Depth, in feet below land surface
$0-10$

$10-30$

$30-40$

$40-60$

$60-100$

$100-116$

$116-140$

$140-150$

Well 2627-2601

Sand, quartz, fine to medium, white to gray

Sand, quartz, fine to very coarse, well-rounded, white, becoming finer in lower part

Sand, quartz, fine, gray, phosphatic

Sand, quartz, coarse to very coarse, white, wellrounded, phosphatic

Gravel, quartz, white to gray, phosphatic

Sand, quartz, fine to very fine, white to pink; clay, green-blue; marl, light brown to buff 


\section{For Reference}

Not to be taken from this room 

